\title{
NETRALITAS NOTARIS SEBAGAI ANGGOTA LEGISLATIF: Studi Tentang Peran Notaris Cuti Sebagai Anggota Legislatif Terhadap Notaris Pengganti Terhadap Akta-akta Yang Dibuatnya
}

\author{
Nur Cahyaningsih* , Akhmad Khisni** \\ * Mahasiswa Program Magister (S2) Kenotariatan Fakultas Hukum UNISSULA, email : maya240414@yahoo.com \\ ${ }^{* *}$ Dosen Fakultas Hukum UNISSULA
}

\begin{abstract}
The Regional People's Legislative Assembly, hereinafter referred to as the Regional People's Legislative Assembly (DPRD), is a representative institution of the regional people as an element of local government administration Legally and politically the DPRD has a strategic position in implementing development policies in the regions. The magnitude of the roles, functions and authorities of the legislature invites many elements of society to enter as members of the council, notary positions and many Land Acquisition Authorities who are left behind to follow the legislative election procession. As a first step, a notary and enter into the party membership, and follow all the procedures of scaling, to then be elected by the community to become members of the council. Notaries in exercising their right to sit on behalf of the community as members of the Council, also regulated in Law No. 7 of 2017 on General Elections, are said to have made a statement willing not to practice as notaries and officials of the land deed (hereinafter referred to as PPAT). From this it can lead to issues of provisions contained in Articles 3 and 17, namely dual positions. This study aims to determine the relationship of notary to leave with a substitute notary in the perspective of Law Number 30 Year 2004 regarding Position Notary. Article explaining, among other things, article 33, on this matter Notary, a Notary substitute has the same authority related to the making of authentic deeds made. The research approach used is normative juridical, which will be qualitatively analyzed normative against secondary data. The theory used by the author is the theory of authority, theory of responsibility and theoretical justice. If you look at the explanation and analyze from the articles of article regarding the Notary Substitute, the Article which explains, among others, article 33, regarding this Notary, the Notary substitute has the same authority regarding the making of authentic deeds made. The authority of notary and substitute notary is based on Article 15 of Law Number 2 Year 2014 concerning Notary Position. The authority of a substitute notary commences from the grant of a notary protocol until the expiry of the appointment period based on the decision of the Notary Supervisory Board. Procedures concerning notary leave with a substitute notary may result in a conflict of interest that may affect the independence of a notary who is not allowed to take sides, this is due to 2 (two) factors namely the rules themselves and the political factor. Procedures concerning notary leave with a substitute notary may result in a conflict of interest that may affect the independence of a notary who is not allowed to take sides, this is due to 2 (two) factors namely the rules themselves and the political factor. The solution is to reinforce the terms of nomination of legeslative members, not just to not practice (leave) but with the resignation as a notary or PPAT and release all attributes (nameplate, practice office, and so on).
\end{abstract}

Keywords: Notary, Authority, Conflict of Interest, Legislative Member

\section{PENDAHULUAN}

Setelah jatuhnya rezim Soeharto pada tahun 1998, telah terjadi dinamika dalam tata kelola ketatanegaraan secara fundamental. Sejak pemerintahan orde baru selama 32 tahun, dibawah bayang-bayang otoritarianisme orde baru dengan sifat sentralistiknya, tiba-tiba harus terhenti oleh derasnya desakan reformasi di semua bidang pemerintahan. Maka, sejak bergeloranya era reformasi, perubahan mendasar dalam tata kelola pemerintahan pun terjadi, sifat sentralistik sebagai ciri khas demokrasi otoritarian dirubah menjadi demokratis (desentralistik). ${ }^{1}$

1 Dr. Pratikno memberikan gambaran tentang sentralistiknya orde baru saat itu dengan.."mekanisme kontrol politik secara nasional tersebut bahu-membahu dengan sentralisasi pengelolaan sumber daya ekonomi secara nasional yang sangat bias pusat (Jakarta dan kemudian Jawa). Dengan adanya wacana pembangunan 
Salah satu pondasi dalam orde reformasi adalah menguatnya isu desentralisasi sebagi solusi atas ketidakmerataannya pembangunan selama presiden soeharto berkuasa. Undang-undang yang menjadi payung terhadap pelaksanaan desentralisasi adalah Undang-undang Nomor 22 Tahun 1999 tentang pemerintahan daerah yang kemudian mengalami perubahan pada tahun 2004 dengan Undang-undang Nomor 32 tahun 2004. Hal yang paling mendasar daripada sistem desentralisasi adalah diberikannya kewenangan daerah untuk mengurus sendiri kepentingan daerah.

Munculnya reformasi sebagai jawaban atas kebuntuan orde baru dalam memberikan jawaban terhadap tantangan negara moderen yang demokratis telah melahirkan konsepsi manajemen publik baru di Indonesia, yang sebenarnya diawali dengan menurunnya kepercayaan dan deligitimasi terhadap negara. Masyarakat berasumsi bahwa birokrasi dan aparatur pemerintahan dijadikan sebagai tameng politik bagi rezim berkuasa. Birokrasi dan aparatur pemerintah dianggap sebagai penyumbat pembangunan. Lebih lanjut, Kumorotomo ${ }^{2}$ menjelaskan, bahwa:

"pada saat yang akan datang, birokrasi maupun pemerintahan memiliki tugas yang tidak ringan untuk kembali mendapatkan trust of social, kecuali mereka dapat membuktikan kepada masyarakat, bahwa semua elemen dan unsur politik maupun public maker yang ada dapat menjamin keberadaannya akan keuntungan bagi semua rakyat Indonesia..."

Sekalipun mendapatkan kepercayaan publik, namun tetap saja pemerintahan daerah dalam konsep desentralisasi dihadapkan pada tuntutan dalam pencapaian pemerintahan yang baik. Di dalam

nasional, pemerataan pembangunan antar daerah dan integrasi nasional, pemerintah melakukan pengelolaan sumber daya ekonomi daerah secara nasional. Pertambangan, hutan, beberapa hasil laut dan beberapa jenis perkebunan dikelola secara nasional yang hasilnya dibawa secara penuh ke Jakarta".. Lihat. Pratikno, Pengelolaan Hubungan Antara Pusat dan Daerah, dalam Desentralisasi dan Otonomi Daerah; Desentralisasi, Demokrasi dan Akuntabilitas Pemerintahan Daerah, LIPI Press, Jakarta, 2005, hal.33

2 Kumorotomo, Akuntabilitas Birokrasi Publik Sketsa pada Masa Transisi, Pustaka Pelajar, Yogyakarta, 2005, hal. 20 undang-undang oronomi daerah, dua unsur penyelenggara pemerintahan daerah adalah Dewan Perwakilan Rakyat (DPRD) yang berperan sebagai lembaga legeslatif, dan satunya adalah lembaga eksekutif daerah yang dipimpin oleh kepala daerah yang berperan sebagai pelaksana dan pengendali roda pemerintahan daerah.

Menurut undang-undang nomor 32 tahun 24 tentang pemerintahan daerah menyebutkan pengertian pemerintahan daerah salah satu unsurnya adalah Dewan Perwakilan Rakyat Daerah atau DPRD yang memiliki pengertian lembaga daerah sebagai unsur penyelenggara pemerintahan daerah yang memiliki kedudukan dan posisi strategis dalam menjalankan fungsi pengawasan dan kontrol kebijakan pembangunan daerah. Sebab, DPRD merupakan lembaga perwakilan masyarakat yang mencerminkan aspirasi masyarakat dan berkedudukan sebagai unsur peyelenggaraan pemerintah daerah, sehingga mampu memberikan pelayanan kepada masyarakat.

Undang-undang No. 32 Tahun 2004 Pasal 45 pada huruf (e) menjelaskan, mengenai kewajiban DPRD untuk menyerap, menampung, menghimpun, dan menindaklanjuti aspirasi masyarakat. Baskoro ${ }^{3}$ menjelaskan bahwa lembaga legeslatif daerah (DPRD) adalah salah satu unsur penyelenggara pemerintahan daerah yang memiliki peran penting, yakni:

1. Menentukan policy (kebijaksanaan dan membuat undang-undang). Untuk itu DPR atau DPRD diberi hak inisiatif, hak untukmengadakan amandemen terhadap rancangan undang-undang ataura ncangan peraturan daerah yang disusun oleh pemerintah serta hak budget.

2. Mengontrol badan eksekutif dalam arti menjaga semua tindakan ekskutif sesuai dengan kebijaksanaan yang telah ditetapkan. Untuk menyelenggarakan tugas ini badan perwakilan rakyat diberi hak-hakkontrol khusus.

Fungsi selanjutnya daripada DPR atau DPRD adalah fungsi budgeting, dimana bersama dengan eksekutif melakukan penyusunan Anggaran Pendapatan dan Belanja Daerah atau biasa disingkat APBD. Anggaran Pendapatan dan Belanja Daerah

\footnotetext{
${ }^{3}$ Baskoro, Evaluasi Kerja Sumber Daya Manusia, Refika Aditama, Bandung, 2001, hal. 15
} 
dalam sistem otonomi daerah memiliki pengertian sebagai rencana dalam bidang keuangan dalam masa tahunan yang dihasilkan dari proses pembahasan dan pergulatan antara eksekutif daerah beserta lembaga legeslatif daerah atau Dewan Perwakilan Rakyat Daerah. Yang ditetapkan dengan peraturan daerah yang akan menjadi dasar dalam pengelolaan keuangan daerah dalam masa satu tahun anggaran. APBD merupakan instrumen penting kebijakan pemerintah daerah, yang tidak bisa dipahami hanya sebagai suatu dokumen keuangan semata, tetapi juga merefleksikan komitmen politik dan prioritas kebijakan sosial ekonomi pemerintah.

Keberadaan lembaga seperti DPRD dalam undang-undang otonomi daerah mengalami dinamisasi yang sangat signifikan, hal ini berbanding lurus dengan tingkat perkembangan dan kedewasaan masyarakat dalam bernegara. Di saat sistem pemerintahan sentralistik, fungsi dan posisi DPRD di di desain hanya sebagi legitimasi kekuasaan orde baru. Ini berbanding terbalik dengan sistem yang dibangun dalam konsep pemerintahan otonomi daerah, maka posisi DPRD memiliki peran sebagai mitra eksekutif. Undang-undang tentang pemerintahan darah Nomor 32 Tahun 2004 menyatakan dengan jelas, bahwa fungsi dan kesusukan DPRD selain sebagi mitra juga memiliki fungsi legeslasi, kontrol dan anggaran. ${ }^{4}$

Maka desentralisasi disini dapat juga dimaknai sebagai pemberian kewenangan (otonom) kepada daerah untuk seluas-luasnya untuk mengelola dan memanfaatkan potensi daerah secara optimal dan berkesinambungan. Namun bukan berarti seperti negara federal, dimana negara bagian memiliki kewenangan yang terlepas dari pemerintah pusat, dalam sistem desentralisasi kewenangn daerah tetap dibatasi baik oleh sistem pengawasan maupun batasbatas kewenagnannya. dapat diartikan sebagai pemberian otonomi daerah seluas-luasnya yang berarti pemberian kewenangan dan kekuasaan kepada daerah untuk mengelola dan memanfaatkan sumber daya daerah secara optimal. Agar tidak terjadi penyimpangan dan penyelewengan, maka pemberian kewenangan dan kekuasaan yang luas tersebut harus diikuti dengan pengawasan yang

\footnotetext{
${ }^{4}$ Wasistiono, S., dan Wiyoso, Y, Meningkatkan Kinerja Dewan Perwakilan Rakyat Daerah (DPRD), Fokusmedia, Bandung, 2009, hal 10
}

kuat. Salah satu peran penguatan pengawasan kewengan daerah otonom diperankan oleh kelembagan legeslatif daerah. Sehingga, konsep desentralisasi sebenarnya menginginkan adanya penguatan peran dan fungsi DPRD dalam pengelolaan daerah otonom.

Dalam sistem negara demokrasi yang menggunakan sistem desentarlisasi fungsi pengawasan melekat pada peran, tugas dan kedudukan Dewan Perwakilan Rakyat Daerah (DPRD), sekaligus fungsi anggaran dan peraturanperatuan daerah. Fungsi pengawasan adalah ruh daripada pengelolaan pemerintahan daerah, sehingga diharapkan ada peran kemitraan daerah antara kepala daerah selaku kepala pemerintahan daerah dan lembaga legeslatif (DPRD) dalam menjalankan 3 fungsi pokoknya tersebut. Sehingga diharapkan aspirasi masyarakat dalam penyelenggaraan pemerintahan dapat berjalan dengan baik dan sesuai dengan amanat konstitusi negara (UUD 1945).

Dalam undang-undang nomor 17 tahun 2014 tentang majelis permusyawaratan rakyat, dewan perwakilan rakyat, dewan perwakilan rakyat, dewan perwakilan daerah dan dewan perwakakilan rakyat daerah menjelaskan bahwa pengawasan merupakan salah satu dari tiga fungsi dewan perwakilan rakyat daerah. Fungsi ini dijalankan dalam bentuk pengawasan terhadap pelaksanaan suatu undangundang, peraturan daerah, maupun kebijakan kebijakan laiinya yang dikeluarkan oleh pemerintah daerah. Tugas dan fungsi dewan perwakilan rakyat daerah selain fungsi budgeting dan legeslasi, adalah fumgsi pengawasan terhadap pelaksanaan peraturan daerah, peraturan perundang-undangan, maupun peraturan-peraturan lainnya yang berkaitan dengan penyelenggaraan pemerintah daerah.

Fungsi pengawasan merupakan fungsi yang melekat pada anggota legeslatif, sehingga fungsi ini merupakan salah satu fungsi yang paling intensif dilakukan oleh anggota dewan terhadap pelaksanaan peraturan daerah. Fungsi pengawasan yang dijalankan oleh DPRD dalam konteks sebagai lembaga politik merupakan bentuk pengawasan politik yang lebih bersifat strategis yang bukan merupakan pengawasan teknis administratif. Salah satu bentuk pengawasannya adalah DPRD bertindak sebagai lembaga pengendali atau pengontrol yang 
dapat menyetujui atau bahkan menolak sama sekali ataupun menyetujui dengan perubahan-perubahan tertentu terhadap rancangan peraturan daerah yang akan ditetapkan menjadi Perda. Hal ini dapat dipahami bahwa sebenarnya lembaga DPRD itu adalah lembaga politik.

Besarnya peran, fungsi dan kewenangan lembaga legislatif tersebut mengundang banyak elemen masyarakat untuk masuk sebagai anggota dewan, baik daerah (kabupaten atau kota, propinsi, terlebih pusat). Pengusaha, birokrat, advokat, dokter, tokoh agama, tokoh masyarakat, dan tidak terkecuali adalah seorang Notaris dan atau PPAT. Fenomena diperebutkannya kursi legeslatif bukanlah terjadi pada akhir-akhir ini saja, sejak zaman kemerdekaan pun sudah menjadi medan perebutan. Hal tersebut dikarenakan kedudukan, tugas dan fungsi anggota dewan dalam struktur pemerintahan daerah maupun pusat begitu diperhitungkan, selain gaji yang cukup besar. $^{5}$

Jabatan Notaris maupun Pejabat Pembuat Akta Tanah banyak yang ditinggalkan untuk mengikuti prosesi pemilu legeslatif. Sebagai langkah awal maka, seorang Notaris maupun pejabat Pembuat Akta Tanah masuk ke dalam keanggotaan partai, dan mengikuti semua prosedur pencalegan, untuk kemudian dipilih oleh masyarakat untuk menjadi anggota dewan.

Bolehkah seorang Notaris maupun Pejabat Pembuat Akta Tanah menjabat sebagai anggota dewan? Pertanyaan semacam ini tentunya harus dirunut dari semua peraturan perundangan yang mengatur tentang jabatan notaris (Undang-Undang Nomor 30 Tahun 2004 tentang Jabatan Notaris), Pejabat Pembuat Akta Tanah (Peraturan Pemerintah Nomor 37 Tahun 1998 juncto Pasal 30 Peraturan Kepala Badan Pertanahan Nasional Nomor 1 tahun 2006) maupun tentang mekanisme ketentuan pencalegan yang termuat dalam Undang-undang

\footnotetext{
5 Legislatif adalah struktur politik yang fungsinya membuat undang-undang. Dimasa kini, lembaga tersebut disebut dengan Dewan Perwakilan Rakyat (yang selanjutnya disingkat DPR) (Indonesia),

House of Representative (Amerika Serikat), ataupun House of Common (Inggris). Lembaga-lembaga ini dipilih melalui mekanisme pemilihan umum yang diadakan secara periodik dan berasal dari partai-partai politik. Lihat. Miriam Budiardjo, Dasar-dasar IImu Politik, Gramedia, Jakarta, 2001, hal 23.
}

nomor 7 tahun 2017 tentang pemilihan umum anggota dewan perwakilan rakyat (DPR), dewan perwakilan daerah (DPD, dan anggota dewan perwakilan rakyat daerah (DPRD). Notaris dalam menggunakan hak nya untuk bisa duduk mewakili masyarakat sebagai anggota dewan juga diatur dalam Undang-undang nomor 7 tahun 2017 tentang pemilihan umum anggota dewan perwakilan rakyat (DPR), dewan perwakilan daerah (DPD, dan anggota dewan perwakilan rakyat daerah (DPRD), pasal 50 ayat (1), disebutkan huruf I bahwa mereka harus membuat pernyataan bersedia untuk tidak berpraktik sebagai notaris dan pejabat pembuat akta tanah (yang selanjutnya disingkat PPAT). Di dalam ketentuan tersebut juga dijelaskan tentang tidak diperbolehkannya melakukan penyediaan barang dan jasa yang berkaitan dengan keuangannegara sertapekerjaan lain yang dapat mengakibatkan konflik kepentingan (conflict of interest) dengan dengan tugas, kewenangan, dan fungsi anggola tegeslatif

Sebagai konsekuaensinya, selain terhadap undang-undang pemilu nomor 7 tahun 2007, dalam pencalonannya atau dalam kedudukannya sebagai notaris, tentunya mereka juga terikat dengan ketentuan perundang-undangan, khusususnya tentang jabatan notaris itu sendiri, dimana pasal 17 huruf $\mathrm{d}$ menyatakan bahwa, notaris dilarang untuk melakukan rangkap jabatan sebagai pejabat negara. Dalam hal ini, ditegaskan bahwa apabila seorang notaris yang terpilih sebagai anggota legeslatif, maka wajib baginya untuk mengambil cuti.

Selama menjalankan tugas jabatannya, notaris berhak untuk cuti, yang dapat diambil setelah menjalankan tugas jabatan selama 2 (dua) tahun. Jumlah keseluruhan cuti yang diambil notaris tidak lebih dari 12 (duabelas) tahun. Sesuai dengan karakter jabatan notaris yaitu harus berkesinambungan selama notaris masih dalam masa jabatannya, maka notaris yang bersangkutan wajib menunjuk notaris pengganti. ${ }^{6}$

Dalam Undang-undang nomor 7 tahun 2017 tentang pemilihan umum anggota dewan perwakilan rakyat (DPR), dewan perwakilan daerah (DPD, dan anggota dewan perwakilan rakyat daerah (DPRD),

6 Habib Adjie, Hukum Notaris Indonesia, PT. Refika Aditama, Bandung, 2008, hal 102. 
pasal 50 ayat (1), disebutkan huruf I bahwa mereka harus membuat pernyataan bersedia untuk tidak berpraktik sebagai notaris dan pejabat pembuat akta tanah (yang selanjutnya disingkat PPAT). Selanjutnya dalam pasal 50 ayat (2) huruf $\mathrm{g}$ diatur bahwa kelengkapan administrasi bakal calon anggota DPR, $D P R D$ provinsi, dan DPRD kabupaten/kota sebagaimana dimaksud pada ayat pertama dibuktikan dengan : "...surat pernyataan kesediaan untuk tidak berpraktik sebagai akuntan publik, advokat/ pengacara, notaris, pejabat pembuat akta tanah (PPAT) yang ditandatangani di atas kertas bermeterai cukup;".

Ketentuan yang sama diperlakukan pula bagi perseorangan sebagai peserta pemilu anggota Dewan Perwakilan Daerah (DPD), yang diataur dalam pasal 12 ayat (1) huruf i undang-undang no 7 tahun 2017. Dari penjalasan diatas, yakni ketentuan yang tercantum dalam pasal 50 ayat pertama huruf $\mathrm{i}$ dan ayat (2) huruf g diatas, maka timbul pertanyaan, apakah rangkap jabatan sebagai anggota Dewan perwakilan Rakyat (DPR) Dewan perwakilan rakyat daerah (DPRD) propinsi dan atau kota, Dewan Perwakilan Daerah (DPD) terlarang bagi seorang notaris? Jawaban terhadap pertanyaan tersebut tentu saja tidak, sebab peraturan itu hanya mengatur tentang "kesediaan untuk tidak berpraktik, dan sekali-kali bukan untuk berhenti sebagai Notaris atau Pejabat Pembuat Akta Tanah (PPAT) selama berstatus sebagai anggota Dewan perwakilan Rakyat (DPR) Dewan perwakilan rakyat daerah (DPRD) propinsi dan atau kota, Dewan Perwakilan Daerah (DPD)".

Mengenai makna terhadap istilah "berpraktek", yang paling tepat dalam hubungannya dengan ketentuan di atas adalah "melaksanakan pekerjaan/jabatan/profesi", dalam hal ini "membuat akta peralihan dan pembebanan hak atas tanah dan hak milik atas satuan rumah susun serta surat kuasa membebankan hak tanggungan". Kesesuaian penafsiran atau pemberian makna tersebut akan lebih nampak lagi bila kita berkenan memperbandingkannya dengan pengaturan yang tercantum dalam Undang-Undang Nomor 18 Tahun 2003 tentang Advokat maupun Undang-Undang Nomor 30 Tahun 2004 tentang Jabatan Notaris.

Dalam pasal 20 ayat (3) Undang-Undang Tentang Advokat dinyatakan bahwa "Advokat yang menjadi pejabat negara, tidak melaksanakan tugas profesi Advokat selama memangku jabatan tersebut". Dalam penjelasan dari ayat yang bersangkutan dinyatakan bahwa "Ketentuan dalam ayat ini tidak mengurangi hak dan hubungan perdata Advokat tersebut dengan kantornya".

Pasal 11 ayat (1) dan (6) Undang-undang nomor 2 tahun 2014 tentang jabatan notaris menyatakan secara berturut-turut sebagai berikut:

(1) notaris yang diangkat menjadi pejabat negara wajib untuk mengambil cuti. (6) notaris yang tidak lagi menjabat sebagai pejabat negara sebagaimana dimaksudkan pada ayat (1) dapat menjalankan kembali fungsi jabatan notarisnya, dan protokolnotaris sebagaimana dimaksud pada ayat (4) diserahkan kembali kepadanya.

Tidak ada kewajiban terhadap Notaris atau PPAT untuk mengajukan permohonan berhenti kepada Kepala Badan Pertanahan Nasional, dan yang bersangkutan tidak pernah kehilangan, oleh karena itu tetap berstatus sebagai Notaris atau PPAT, hanya saja tidak berpraktik.

Apabila seorang pejabat Notaris atau PPAT yang menjadi anggota dewan dan digantikan oleh notaris pengganti apakah notaris yang cuti sebagai anggota dewan bisa dijamin kenetralitasannya terhadap akta-akta yang dibuat oleh notaris pengganti? Apakah ada jaminan bahwa seorang anggota dewan yang cuti tidak memberikan pengaruh kepada lembaga eksekutif (BUMD, BUMN) untuk bermitra dengan kantor notaris tempat ia berpraktik dahulu? Ini tentunya berkaitan dengan strategisnya jabatan seorang angota dewan baik daerah, propinsi terlebih anggota legeslatif pusat dalam kapasitas tugas pokok dan fungsinya (budgeting, legeslasi dan kontrol).

Penelitian ini penting berkaitan dengan larangan rangkap jabatan seperti dalam undangundang jabatan notaris, namun berkaitan dengan netralitas, kredibilitas dan tanggung jawab baik bagi notaris yang cuti sebagai anggota Dewan, terlebih bagi notaris penggantinya, karena akan berkaitan dengan akta-akta yang akan dibuatnya. Sehingga kami mengambil judul NETRALITAS NOTARIS SEBAGAI ANGGOTA DEWAN: Studi Tentang Peran Notaris Cuti Sebagai Anggota Legislatif Terhadap 
Notaris Pengganti Atas Akta-akta Yang Dibuatnya

Terhadap uraian di atas, maka ada 2 (dua) persoalan yang dapat dirumuskan dalam pembahasan penelitian ini, yakni: Bagaimana peran, tugas pokok anggota legeslatif dalam penyelenggaraan pemerintahan daerah? Bagaimana hubungan notaris cuti dengan notaris pengganti dalam perspektif undang-undang nomor 2 tahun 2014 tentang Jabatan Notaris? Bagaimana hambatan serta solusinya untuk menjaga netralitas seorang notaris atau PPAT yang menjadi anggota legislatif terhadap notaris penggantinya?

Pertanyaan pertama akan mengupas tentang kiprah dan peran-peran seorang anggota legeslatif dalam hubungannya dengan mitra kerja (eksekutif). Pertanyaan ini pula yang akan menjawab bagaimana fungsi kontrol yang diperankan anggota dewan yang cuti sebagai notaris terhadap jajaran eksekutif (BUMD, Birokrasi Pemerinahan, Lembaga Keuangan Daerah) untuk mengarahkan perjanjian, kontrak dan peristiwa perdata lainnya di Kantor Notaris dahulu ia praktik.

Selanjutnya pertanyaan kedua akan mengarahkan pada sejauh mana undang-undang nomor 2 tahun 2014 tentang jabatan notaris mengatur tentang hubungan cuti notaris dengan notaris pengganti, hak serta keajiban masing-masing pihak, sehingga akta-akta yang dibuat oleh notaris pengganti benar-benar memiliki kekuatan pembuktian yang kuat, karena bebas dari interfensi pihak manapun.

\section{METODE PENELITIAN}

Sebagai langkah untuk mendapatkan tujuan dalam penelitian ini maka pilihan metodologi penelitian merupakan suatu hal yang mendasar, sehingga diharapkan tujuan dan harapan dalam penulisan dapat tercapai. Metodologi penulisan yang akan digunakan dalam penelitian ini masuk dalal jenis penelitian yuridis normatif. Penelitian ini mendasarkan pada pendekatan terhadap asas mamupun aturan-aturan hukum yang akan berhubungan dengan undang-undang jabatan notaris dan peraturan-peraturan yang berkaitan dengan pemilihan umum. Pendekatan ini dimaksudkan untuk mengetahui variabel-variabel yang mempengaruhi keberlakuan hukum yang bertumpu pada data-data skunder.

Jenis data yang digunakan dalam penelitian ini adalah data sekunder. Data sekunder merupakan jenis data yang digunakan untuk menunjang kelengkappan data primer yang dapat diperoleh melalui perpustakaan maupun e-book yang tersebar di internet.

\section{PEMBAHASAN}

Pengertian notaris secara umum adalah pejabat yang berwenang untuk membuat akta otentik terhadap suatu perbuatan hukum baik itu terhadap suatu perjanjian maupun penetapan yang diharuskan oleh suatu peraturan perundang-undangan atau bisa pula oleh mereka yang memiliki kepentingan menghendaki agar dituangkan kedalam suatu akta otentik, menjamin kepastian hukum, salinan maupun kutipannya, menimpan akta dan memberikan grosse, dan semuanya sepanjang penyusunan akta tersebut tidak dilarang oleh ketentuan peraturan perundangundangan serta tidak pula ditugaskan maupun dikecualikan kepada pejabat publik lainnya.

Dengan demikian maka, jabatan notaris mendasarkan kinerjanya pada moral serta nilai etik, sehingga peranan notaris yang sesungguhnya adalah pelayanan kepada masyarakat secara mandiri dan tidak memihak (independent).sampai disini maka peranan notaris dalam kehidupan masyarakat seharihari merupakan panggilan hidup yang bersumber pada semangat pengabdian terhadap masyarakat demi kepentingan umum .

Jabatan dijalankan oleh pribadi sebagai wakil dalam kedudukan demikian dan berbuat atas nama jabatan, yang disebut pemangku jabatan.Secara teoritis, tata cara pengisian jabatan yang baik telah dikemukakan olehLogemann berpendapat, bagian yang terbesar dari Hukum Negara(Staatsrecht) adalah peraturan-peraturan hukum yang menetapkan secaramengikat bagaimana akan terbentuknya organisasi negara itu.

Hambatan dalam menjaga netralitas notaris yang cuti Sebagai anggota dewan terhadap notaris pengganti

Dalam pelaksanaannya seorang notaris yang cuti menjadi anggota legeslatif, maka ia akan sulit untuk menjaga netralitasnya, paling tidak ada dua 
aspek yang menjadikan hambatan dalam peprsoalan ini, yakni aspek peraturan-perundangan dan aspek politis.

\section{Aspek peraturan perundangan.}

Di dalam Pasal 11 UUJN menyebutkan bahwa notaris yang diangkat sebagai pejabat negara wajib mengambil cuti. Notaris yang cuti menjadi pejabat negara ini wajib menunjuk notaris pengganti dan bilamana tidak menunjuk notaris pengganti, maka Majelis Pengawas Daerah menunjuk notaris lain untuk menerima protokol Notaris yang cuti tersebut.

Selanjutnya Notaris pemegang Protokol tersebut merupakan pemegang sementara Protokol Notaris. Notaris yang tidak lagi menjabat sebagai pejabat negara tersebut dapat menjalankan kembali jabatan notarisnya dan menerima kembali Protokolnya dari pemegang Protokol sementara.

Pasal 3 huruf (g) UUJN mensyaratkan untuk dapat diangkat menjadi notaris harus tidak berstatus sebagai pegawai negeri, pejabat negara, advokat atau tidak sedang memangku jabatan dan yang oleh Undang-undang dilarang untuk dirangkap jabatannya. Pasal 17 huruf (c), (d), (e), (f) juga merupakan larangan kepada notaris untuk merangkap sebagai pegawai negeri, pejabat negara, advokat, dan jabatan sebagai pimpinan dan pegawai Badan Usaha Milik Negara, Badan Usaha Milik Daerah dan Badan Usaha Swasta.

a. Jika Pasal 11 UUJN kita kaitkan dengan kedua Pasal tersebut maka jelas ketentuan yang diatur dalam Pasal 11 tentang cuti notaris sebagai pejabat negara melanggar Pasal 3 huruf $(\mathrm{g})$ yaitu persyaratan untuk menjadi Notaris tidak berstatus sebagai Pejabat Negara. Persyaratan yang diharuskan dalam Pasal 3 huruf $(\mathrm{g})$ ini melekat pada jabatan sebagai Notaris sepanjang waktu Notaris tersebut sampai dengan berhenti atau diberhentikan atau meninggal atau karena masa jabatan Notaris telah berakhir/pensiun.

b. Pasal 17 huruf (d) memberikan larangan kepada Notaris untuk merangkap jabatan sebagai Pejabat Negara.

Oleh karena itu bila dicermati ketentuan di Pasal 11 ini terdapat inkonsistensi antara Pasal 11 dengan Pasal 3 dan Pasal 17 UUJN. Dengan kata lain ketentuan di pasal-pasal tersebut bersifat ambiguous, tidak konsisten dalam memberikan kepastian hukum.
Walaupun Pasal 11 juga dalam ayatnya menyebutkan bahwa Notaris yang sedang cuti sebagai Pejabat Negara itu wajib menunjuk Notaris Pengganti atau bila tidak menunjuk maka Majelis Pengawas Daerah yang akan menunjuk pemegang Protokol sementara, sebenarnya di sini tetap terdapat secara terselubung pelanggaran terhadap Pasal 3 huruf (g) dan Pasal 17 huruf (d) yaitu Notaris dilarang untuk rangkap jabatan. Rangkap jabatan ini dapat dibuktikan dalam pelaksanaan jabatan oleh Notaris Pengganti dari Notaris yang sedang cuti sebagai Pejabat Negara tersebut, yaitu:

a. Seorang notaris pengganti dalam melaksanakan jabatannya mempunyai tanggung jawab yang sama dengan Notaris yang digantikannya seperti yang tercantum dalam Pasal 15, pasal 16, Pasal 17 UUJN. Dalam setiap pembuatan akta, Notaris Pengganti tersebut pada kepala akta harus menyebutkan Surat Keputusan Pengangkatannya sebagai pengganti dari Notaris yang sedang cuti tersebut.

Contoh: "...berhadapan dengan saya, Nurcahyaningsih, Sarjana Hukum, berdasarkan Surat Keputusan Majelis Pengawas Daerah tanggal 11-12-2016 (sebelas Desember dua ribu enam belas) nomor 1/cuti/MPD-Batang/2016 sebagai Pengganti dari Srihadi, Sarjana Hukum, Magister Kenotariatan, Notaris, di Kabupaten Batang..."

Hal ini jelas nama notaris yang sedang cuti sebagai pejabat negara tersebut senantiasa disebutkan pada setiap akta yang dibuat oleh notaris pengganti.

b. Protokol yang dipergunakan oleh Notaris Pengganti adalah tetap Protokolnya Notaris yang sedang cuti tersebut, yaitu antara lain :

- Buku daftar akta (Reportorium)

- Buku daftar akta di bawah tangan yang disahkan

- Buku daftar akta yang di bawah tangan yangn di daftar

- Buku daftar wasiat

- Buku daftar protes

- Buku klaper

c. Kantor yang dipergunakan adalah tetap kantor Notaris yang sedang mengambil cuti tersebut. Pegawai-pegawai dan semua alat kantor tetap memakai kepunyaan Notaris yang sedang 
mengambil cuti sebagai Pejabat Negara tersebut.

d. Papan nama Notaris yang sedang cuti tetap masih terpampang.

e. Kop-kop surat semuanya masih memakai kop surat notaris yang sedang cuti

\section{Aspek politis}

Strategisnya peran dan tugas anggota DPRD dalam penyelenggaraan pemerintahan daerah membuat anggota legeslatif atau notaris cuti dapat memberikan pengaruh terhadap notaris pengganti. Paling tidak ada 2 hal yang memungkinkan notaris cuti sebagai anggota dewan melakukan disfungsi:

a. Anggota legeslatif (notaris cuti) dapat dengan mudah mengarahkan perusahaan-perusahaan daerah, instansi (OPD) maupun lembaga keuangan milik daerah untuk menjadi rekanan di kantor notaris penggantinya.

b. Dalam kapasitasnya sebagai unsur penyelenggara pemerintahan daerah anggota legeslatif (notaris cuti) dapat menginterfensi klausul akta yang dibuat oleh notaris pengganti.

\section{Solusi dalam menjaga netralitas notaris yang cuti sebagai anggota dewan terhadap notaris pengganti.}

Walaupun pertanggungjawaban notaris pengganti dengan notaris cuti telah diatur dalam Undang-Undang Nomor 2 Tahun 2014 tentang Jabatan Notaris, yaitu pertanggungjawaban perdata dan pertanggungjawaban administrasi, namun penulis beranggapan perlu dilakukannya batasanbatasan hubungan antara notaris pengganti dengan notaris cuti:

1. memindahkan kantor berpraktik notaris cuti dengan notaris pengganti, termasuk tidak menggunakan papan nama notaris cuti di kantor notaris pengganti;

2. seperti halnya pejabat umum lainnya, maka notaris yang akan mencalonkan sebagai anggota legeslatif harus mengundurkan sebagai notaris.

\section{KESIMPULAN}

Dari pembahasan diatas, maka penulis dapat menarik beberepa kesimpulan sebagai jawaban terhadap rumusan masalah dalam bab di atas, sebagai berikut:

1. Lembaga legeslatif daerah atau Dewan Perwakilan Rakyat Daerah merupakan suatu unsur lembaga dalam penyelenggaraan pemerintahan daerah selain kepala daerah, sehingga memiliki peran dan fungsi strategis dalam menentukan pembangunan daerah. Dijelaskan dalam UU Nomor 7 tahun 2017, bahwa DPRD terdiri atas anggota partai politik peserta pemilu yang dipilih melalui pemilihan umum.

2. Kewenangan notaris dan notaris pengganti didasarkan pada Pasal 15 Undang-Undang Nomor 2 Tahun 2014 tentang Jabatan Notaris. Notaris pengganti tidak dapat bertangungjawab dalam melakukan perubahan akta (renvoi) atas akta notaris yang digantikannya, notaris pengganti hanya bertanggungjawab terhadap akta yang dibuat oleh dirinya sendiri pada masa pengangkatan sebagai notaris pengganti.

3. Prosedur mengenai notaris cuti dengan notaris pengganti di masa yang akan datang bisa mengakibatkan konflik kepentingan yang dapat mengurangi kredibilitas dan independensi seorang notaris pengganti, yang yang pada prinsipnya memiliki kemandirian sehingga tidak berpihak kepada siapapun. posisi dapat mempengaruhi kemandirian seorang notaris yang tidak boleh memihak, hal ini disebabkan oleh 2 (dua) faktor yakni peraturan-perundangan itu sendiri dan faktor politis. Solusinya adalah mempertegas syarat pencalonan anggota legeslatif, bukan hanya sekedar untuk tidak berpraktik (cuti) namun dengan pengunduran diri sebagai notaris atau PPAT dan melepaskan seluruh atribut (papan nama, kantor praktik, dan sebagainya).

\section{Daftar Pustaka}

A. B. Barrul Fuad. 2000. DPRD Dalam Masa Transisi Menuju Demokrasi. Jurnal Administrasi Negara: Vol. 1. No. 1.

Bachrul Amiq. 2010. Aspek Hukum Pengawasan Pengelolaan Keuangan Daerah Dalam Perspektif Penyelenggaraan Negara Yang Bersih. Yogyakarta: LaksBang PRESSindo.

Habib 2011. Aspek Pertanggung Jawaban 
Notaris Dalam Pembuatan Akta. Bandung: Mandar Maju, Bandung.

Jimly Asshiddiqie. 2009. Menuju Negara Hukum Yang Demokratis. Jakarta: Buana Ilmu Populer.

Komar Andasasmita. 1981. Notaris I. Bandung: Sumur Bandung.

M. Solly Lubis. 2011. Serba-Serbi Politik dan Hukum. Jakarta: Sofmedia.

Mardiasmo. 2002. Otonomi Daerah dan Menejemen Keuangan Daerah. Yogyakarta: Andi.

Marzuki Lubis. 2011. Pergeseran Garis Peraturan Perundang-Undangan Tentang DPRD dan Kepala Daerah Dalam Ketatanegaraan Indonesia. Bandung: Mandar Maju.

Muhammad Ilham Arisaputra. 2012. Kewajiban Notaris Dalam Menjaga Kerahasian Akta Dalam Kaitannya Dengan Hak Ingkar Notaris.
Jurnal Perspektif: Vol. XVII. No. 3.

Pratikno. 2005. Pengelolaan Hubungan Antara Pusat dan Daerah, dalam Desentralisasi dan Otonomi Daerah; Desentralisasi, Demokrasi dan Akuntabilitas Pemerintahan Daerah. Jakarta: LIPI Press.

Ridwan HR. 2002. Hukum Administrasi Negara. Jakarta: Rajawali Press.

Samuel Hutabarat. 2006. Kewajiban dan Kewenangan Majelis Pengawas Notaris. Gloris Yuris: Vol. 6.No. 3.

\section{Perundang-undangan:}

Undang-undang Npmpr 23 tahun 2014

Undang-undang Nomor 7 tahun2017 tentang pemilu Undang-undang nomer 2 tahun 2014 trntang jabatan notariis 